\title{
Antibacterial Activity Test of Red Ginger Extract (Zingiber officinale var. rubrum) Against Streptococcus pyogenes in vitro
}

\author{
Samira Assegaf ${ }^{1}$, Arthur Pohan Kawilarang ${ }^{2 *}$, Retno Handajani ${ }^{3}$ \\ ${ }^{1}$ Faculty of Medicine, Universitas Airlangga, Surabaya, Indonesia \\ ${ }^{2}$ Department of Microbiology, Faculty of Medicine, Universitas Airlangga, Surabaya, Indonesia \\ 3Department of Biochemistry, 00Faculty of Medicine, Universitas Airlangga, Surabaya, Indonesia
}

\section{A R T I C L E I N F O}

\section{Article history:}

Received 13 May 2020

Received in revised form 28 May

2020

Accepted 03 June 2020

Available online 30 June 2020

Keywords:

Red ginger,

Zingiber officinale var. rubrum,

Streptococcus pyogenes,

sore throat.

*) Corresponding author:

arthurkawilarang@gmail.com

\begin{abstract}
A B S T R A C T
Introduction: Red ginger (Zingiber officinale var. rubrum) is known as an antibacterial agent. Streptococcus pyogenes is the most common bacterial cause of pharyngitis in children and adults. Over the years, antibiotic resistance case is increasing. Therefore, further research of other substances to find an bactericidal or bacteriostatic agent is needed. The aim of this study is to determine the Minimum Inhibitory Concentration (MIC) and Minimum Bactericidal Concentration (MBC) of Z. officinale var. rubrum against $S$. pyogenes.

Methods: Serial dilution test of red ginger extract in Mueller hinton broth (8 concentrations of red ginger extract : $80 \%, 40 \%, 20 \%, 10 \%, 5 \%, 2,5 \%, 1,25 \%$, and $0,625 \%$ ) and positive control ( $1 \mathrm{ml}$ bacterial suspension in Mueller hinton broth) was used to determine MIC. MBC was determined by culturing solutions from the previous dilution test into blood agar plate.1 Results: MIC of red ginger extract against $S$. pyogenes could not be determined because the color of red ginger extract affected the turbidity of the dilution test result. MBC of red ginger extract against $S$. pyogenes was at concentration $20 \%$ of red ginger extract.

Conclusion: $Z$. officinale var. rubrum showed antibacterial activity against $S$. pyogenes.
\end{abstract}

\begin{abstract}
Introduction
Pharyngitis is common in children and adults. Pharyngitis is can be caused by viral or bacterial infection. Approximately, $25 \%$ of acute pharyngitis is happened because of group A Streptococcus $\beta$ hemolytic's infection. ${ }^{1}$ In 2010, a study about streptococcal pharyngitis showed that $37 \%$ of children infected by group A of Streptococcus $\beta$ hemoliticus grup A. ${ }^{2}$ People often assumed that pharyngitis or sore throat is a mild and self-limiting disease, so they do not visit a doctor and let it recovered by itself. However, pharyngitis that caused by Streptococcus $\beta$ hemoliticus grup A must be handled properly, because it could complicate to more serious diseases such as rheumatic heart disease and acute rheumatic fever. ${ }^{3}$ Research in 1999 also proved that Streptococcus $\beta$ hemolytic group A infection could make an acute glomerulonephritis which ultimately lead to chronic kidney failure. ${ }^{4} S$. pyogenes is classified into Streptococcus $\beta$ hemolytic group A. People often treated sore throat using ginger. They trusted this method could reduce or
\end{abstract}

even eliminate the sore throat. Kim, et al. in 2005 found that ginger had an anti-inflamation and analgetic agent. ${ }^{5}$ Ginger extract also demonstrated the ability to inhibit the growth of Streptococcus mutans, Staphylococcus aureus, Escherichia coli and Candida albicans. ${ }^{6,7}$ Ginger contained limonene and sesqui-caryophellene as antibacterial agent. ${ }^{8}$ They included in terpene class which was contained in oleoresin of ginger. ${ }^{9}$ Red ginger contained oleoresin more than the other types of ginger, it is considered to have an important role in medicine world. ${ }^{9}$ This time, treatment of pharyngitis is still limited to penicillin and bacitracin. In recent years, many cases of Streptococcus pyogenes's resistance to bacitracin and penicillin has found in various countries. ${ }^{10}$ In Kolkata, India, research in 2010 show high number of Streptococcus pyogenes resistance's cases in children. ${ }^{11}$ Therefore, reasearch of natural ingredients which have bactericidal effect especially for $S$. pyogenes is 
important to decrease bacterial resistance.

\section{Methods}

The research was conducted on February 2015 until August 2015, in the Department of Microbiology, Faculty of Medicine, Universitas Airlangga. Fresh red gingers (Z. officinale var. rubrum) were extracted at Materia Medika, Batu, Indonesia. Extraction procedures were done according to the rule which made by Materia Medika. Three kilograms of fresh red gingers were proceeded into 200 grams of red ginger powder. Then, the red ginger powder was extracted using etanol $96 \%$ solution. At the end of process this extract was evaporated using rotatory evaporator $40^{\circ} \mathrm{C}$ to get a pure extract. The $S$. pyogenes obtained from Microbiology Laboratory of Faculty of Medicine Universitas Airlangga.

This research used 8 concentrations with 2 control tubes. Positive control made from 1 inoculating loop (about 3-4 colonies) of $S$. pyogenes in $1 \mathrm{~mL}$ Mueller Hinton broth ( 0.5 McFarland), then negative control made from $1 \mathrm{ml}$ red ginger extract with a concentration of $80 \%$ in 1 $\mathrm{ml}$ Mueller Hinton broth. This study used serial dilution of red ginger extract in Mueller Hinton broth. The red ginger extract with concentration about $40 \%$ made from $1 \mathrm{~mL}$ of red ginger extract with concentration about $80 \%$ from first tube in $1 \mathrm{~mL}$ Mueller hinton broth in second tube. The red ginger extract with concentration about 20\%, 10\%, 5\%, $2.5 \%, 1.25 \%$ and $0.625 \%$ was made with same method as before (mixing $1 \mathrm{~mL}$ red ginger extract from previous tube with $1 \mathrm{~mL}$ Mueller hinton broth in the next tube) on each available tube. After making all concentrations of red ginger extract, then $1 \mathrm{~mL}$ of bacterial suspension added to each tube. Afterthat, all tubes incubated in $37^{\circ} \mathrm{C}$ for $18-24$ hours in incubator. Four times replication were conducted for high accuracy.

Minimum Inhibitory Concentration (MIC) was determined by naked eye inspection at the smallest concentrations which was still able to inhibit the growth of bacteria (marked with a clear solution). Minimum Bactericidal Concentration (MBC) was determined by streaking test of solutions from previous dillution test on blood agar plate and incubated at $37^{\circ} \mathrm{C}$ for $18-24$ hours. $\mathrm{MBC}$ was the smallest concentration that could kill bacteria marked by the absence of growth on the media.

\section{Results}

After incubation for 24 hours, the turbidity of each tube could be assessed. Table 1 shows the MIC (4 times replication) of the red ginger extract (Z. officinale var. rubrum) against S.pyogenes.

In this study, MIC of red ginger extract (Z. officinale var. rubrum) against $S$. pyogenes could not be determined because the color of red ginger extract affected the turbidity of the dilution test's result. MBC of red ginger extract $(Z$. officinale var. rubrum) against $S$. pyogenes was determined by streaking all available concentrations in blood agar plate.

After incubation for 24 hours, the results of streaking process on a blood agar plate showed that in concentration of red ginger extract at least $20 \%$ there was no bacterial growth in all replications. All replications showed the same MBC. In this study, it could be concluded that the Minimum Bactericidal Concentration (MBC) of red ginger extract (Zingiber officinale var. rubrum) against Streptococcus pyogenes was at concentration about $20 \%$ of red ginger extract.

Table 1. MIC of Red Ginger Extract (Z. officinale var. rubrum) Against S. pyogenes

\begin{tabular}{|c|c|c|c|c|c|c|c|c|c|c|}
\hline \multirow{2}{*}{ Replication } & \multirow{2}{*}{$\begin{array}{c}(+) \\
\text { Control }\end{array}$} & \multirow{2}{*}{$\begin{array}{c}(-) \\
\text { Control }\end{array}$} & \multicolumn{8}{|c|}{ Extract Concentration } \\
\hline & & & $80 \%$ & $40 \%$ & $20 \%$ & $10 \%$ & $5 \%$ & $2,5 \%$ & $1,25 \%$ & $0,625 \%$ \\
\hline I & +++ & - & N.D & N.D & N.D & N.D & N.D & N.D & N.D & N.D \\
\hline II & +++ & - & N.D & N.D & N.D & N.D & N.D & N.D & N.D & N.D \\
\hline III & +++ & - & N.D & N.D & N.D & N.D & N.D & N.D & N.D & N.D \\
\hline IV & +++ & - & N.D & N.D & N.D & N.D & N.D & N.D & N.D & N.D \\
\hline
\end{tabular}

Description:

N.D : Not determined

$++\quad$ : high-density colonies of Streptococcus pyogenes

- $\quad$ : no colony of Streptococcus pyogenes

Table 2. MBC of Red Ginger Extract Against Streptococcus pyogenes

\begin{tabular}{|c|c|c|c|c|c|c|c|c|c|c|}
\hline \multirow{2}{*}{ Replication } & \multirow{2}{*}{$\begin{array}{c}(+) \\
\text { Control }\end{array}$} & \multirow{2}{*}{$\begin{array}{c}(-) \\
\text { Control }\end{array}$} & \multicolumn{8}{|c|}{ Extract Concentration } \\
\hline & & & $80 \%$ & $40 \%$ & $20 \%$ & $10 \%$ & $5 \%$ & $2.5 \%$ & $1.25 \%$ & $0.625 \%$ \\
\hline $\mathrm{I}$ & +++ & - & - & - & + & +++ & +++ & +++ & +++ & +++ \\
\hline II & +++ & - & - & - & + & +++ & +++ & +++ & +++ & +++ \\
\hline III & +++ & - & - & - & + & +++ & +++ & +++ & +++ & +++ \\
\hline IV & +++ & - & - & - & + & +++ & +++ & +++ & +++ & +++ \\
\hline
\end{tabular}

Description :

$+\quad$ : minimum colony growth of Streptococcus pyogenes

$++\quad$ : high-density colonies of Streptococcus pyogenes

- $\quad$ : no colony of Streptococcus pyogenes 


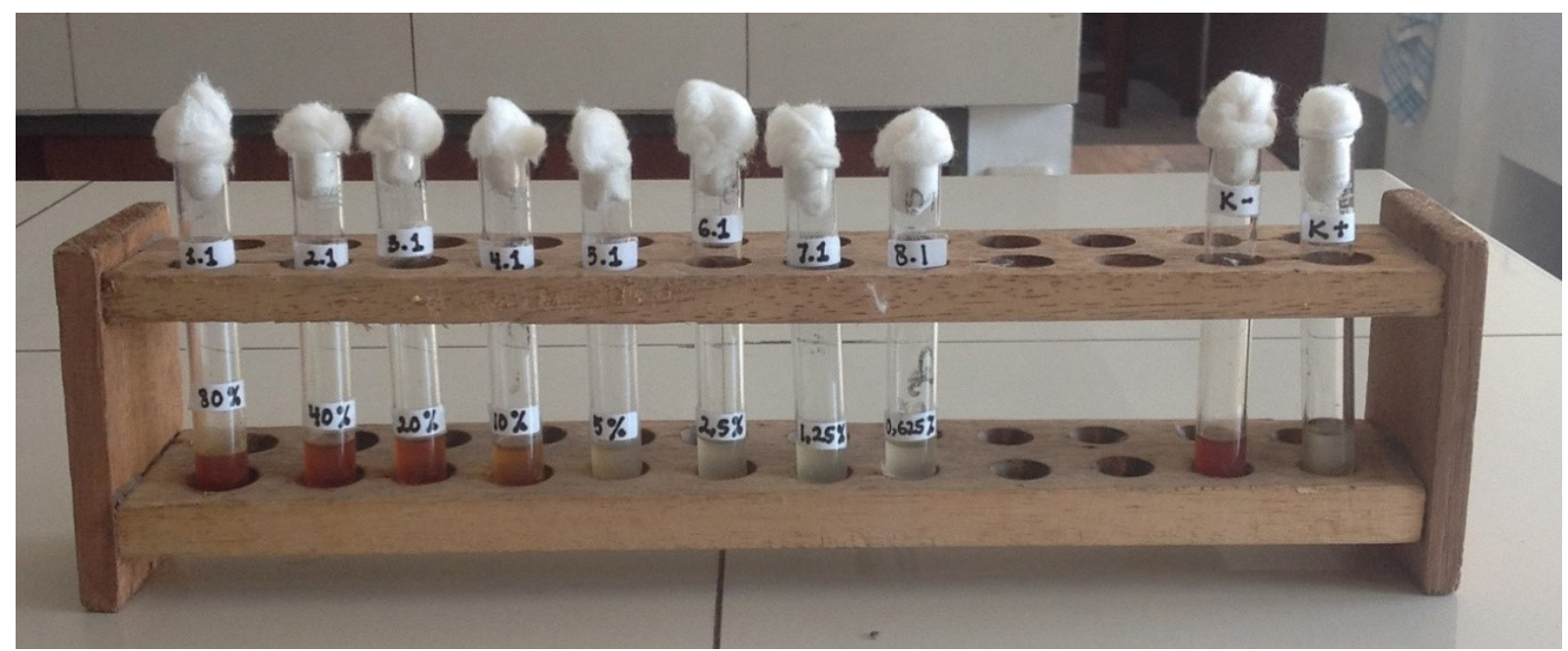

Figure 1. Result from serial dilution test of red ginger extract in Mueller hinton broth. Tube 1.1 contained mixture of red ginger extract with concentration $80 \%$ in $1 \mathrm{~mL}$ of Mueller hinton broth with $1 \mathrm{~mL}$ of bacterial suspension. Tube 2.1, 3.1, 4.1, 5.1, 6.1, 7.1, 8.1 contained mixture of $1 \mathrm{ml}$ bacterial suspension with $1 \mathrm{ml}$ red ginger extract in $1 \mathrm{ml}$ of Mueller hinton broth with each concentration about $40 \%, 20 \%, 10 \%, 5 \%, 2.5 \%, 1.25 \%$ and $0.625 \%$. K- was negative control, made from $1 \mathrm{~mL}$ red ginger extract with concentration about $80 \%$ in $1 \mathrm{~mL}$ Mueller hinton broth and $\mathrm{K}+$ was positive control, made from $1 \mathrm{~mL}$ bacterial suspension in $1 \mathrm{~mL}$ Mueller hinton broth). All tubes had turbid color, so the MIC could not be determined.
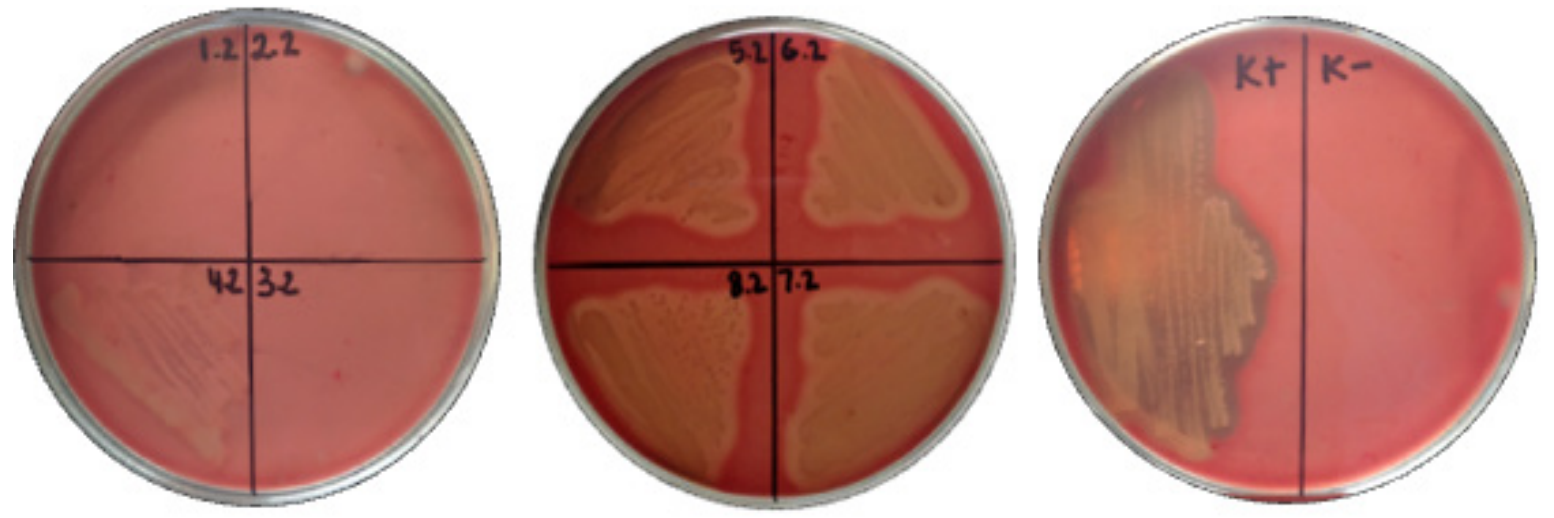

Figure 2 : Dilution test result cultured into Blood Agar Plate. In $1.2(80 \%), 2.2(40 \%)$, and $3.2(20 \%)$ culture there were no growth of S. pyogenes meanwhile in $4.2(10 \%), 5.2(5 \%), 6.2(2,5 \%), 7.2(1,25 \%), 8.2(0.625 \%)$ there were growth of $S$. pyogenes.

\section{Discussion}

Red ginger (Z. officinale var. rubrum) had an antibacterial activity against $S$. pyogenes. Basically red ginger ( $Z$. officinale var. rubrum) contains various compounds that have antimicrobial potential, contained in whole oleoresin and its essential oil. Such compounds include gingerol, limonene, sesquiterpene alcohol/zingiberol, linalool, geraniol and sitral. ${ }^{12}$ Oleoresin is a combination of essential oils and resin. ${ }^{12}$ Whole oleoresin contains one compound that has antimicrobial activity. It is gingerol that performs the function of antimicrobial in 2 ways, first by denature the protein and second by damage the cytoplasmic membrane of bacteria. ${ }^{13}$ The essential oil contains some compounds inside that have antimicrobial activity. One of them is the group of terpenoid compounds. There are 2 classes of terpenoid compounds contained in essential oils, limonene and sesquiterpen alcohol/ zingiberol. ${ }^{8}$ Both of them have the ability to damage the structural components of bacterial cell membrane. Besides that, there are other compounds inside the essential oil that also have antimicrobial activity. They are linalool, geraniol and citral. Linalool and geraniol cause the microbial protein denaturation. Sitral performs the function of antimicrobial compound in 2 ways. It makes the alkylation process at nucleophilic groups and denaturation process in microbial protein. This triggers inactivation of the enzyme inside the bacteria. ${ }^{13}$ Mechanisms of various active compounds against Streptococcus pyogenes show in the following chart : 


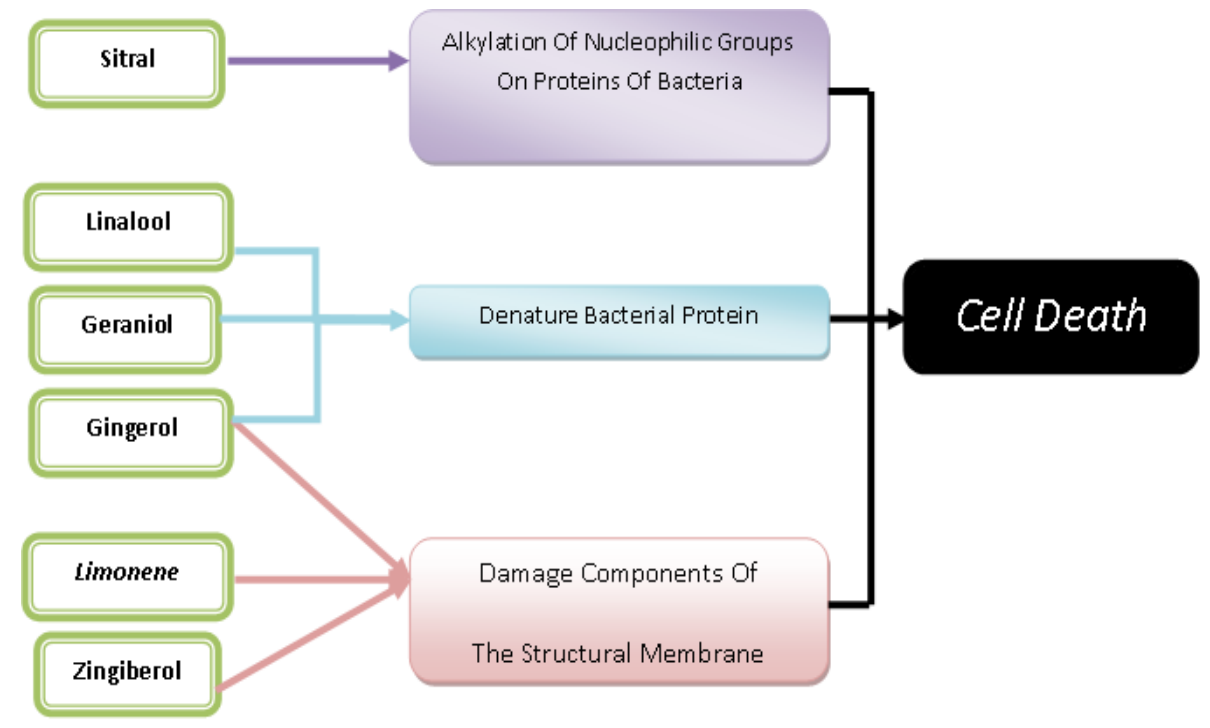

Figure 3 : Mechanisms Antibacterial Active Compounds Contained in Red Ginger ( Z. officinale var. rubrum)

Various active compounds that contained in red ginger (Z.officinale var. rubrum) are mutually cooperate in the fight against bacteria. This actions can inhibit growth of bacteria or even kill the bacteria. In this study, the results showed that the Minimum Bactericidal Concentration (MBC) of red ginger extract (Z. officinale var. rubrum) against $S$. pyogenes at all replication was $20 \%$. This shows that the red ginger (Z. officinale var. rubrum) was able to kill $S$. pyogenes in concentration of $20 \%$ with $100 \%$ power of kill. Based on the experimental results, the red ginger (Z.officinale var. rubrum) had a good potential to be a natural antibacterial agent against $S$. pyogenes in the future. Further research on red ginger was required to reveal the other abilities of red ginger extract to fight bacteria so the resistancy could be minimalized.

\section{Conclusion}

In this research, MIC was difficult to determine because red ginger extract had a turbidity itself so this situation brought an impact to the result of serial dilution test. MBC of red ginger extract (Z. officinale var. rubrum) against S.pyogenes in this study was in concentration of red ginger extract about $20 \%$. From this data we could conclude that the red ginger extract ( $Z$. officinale var. rubrum) had antibacterial activity against $S$. pyogenes.

\section{Conflict of Interest}

The author stated there is no conflict of interest

\section{References}

1. Nasution M. Infeksi Laring faring (Faringitis Akut). USU e-Repository. 2008.

2. Saikh N, Leonard E, M. Martin J. Prevalence of Streptococcal Pharyngitis and Streptococcal Carriage in Children : A Meta-analysis.
Pediatrics 2010;126:557-64.

3. Endang Rahayuningsih S. Demam Rematik Akut. Pustaka Unpad 2011:1-15. (online access : http://pustaka.unpad.ac.id/wp-content/ uploads/2013/12/Pustaka Unpad Demam Rematik Akut.pdf)

4. Agung Fitri Kusuma S. Streptococcus pyogenes. Pustaka Unpad 2010:1-14. (online access : http://pustaka.unpad.ac.id/wp-content/ uploads/2011/09/pustaka_unpad_streptococcus-pyogenes.pdf )

5. Hernani, W C. Kandungan Bahan Aktif Jahe dan Pemanfaatannya dalam Bidang Kesehatan. Status Teknologi Hasil Penelitian Jahe 2010:125-42.

6. A G, GY Y. Assesement of Antimicrobial Potential of $10 \%$ Ginger Extract Against Streptococcus mutans, Candida albicans and Enterococcus faecalis : An In Vitro Study. Indian J Dent Res. 2013;24:397-400.

7. Indah Permatasari K, Periadnadi, Nasir N. Uji Antimikroba Ekstrak Segar Jahe-Jahean (Zingiberaceae) terhadap Staphylococcus aureus, Escherichia coli dan Candida albicans. Jurnal Biologi Universitas Andalas (J Bio UA). 2013;2 20-4.

8. Abdul Hamid A, Permatasari N, Kristiawan G. Efek Ekstrak Jahe (Zingiber officinale) terhadap Pertumbuhan Methicillin Resistant Staphylococcus aureus In Vitro. 2012:1-8.

9. Eka Wahyu Lestari W. Pengaruh Nisbah Rimpang dengan Pelarut dan Lama Ektraksi terhadap Mutu Oleoresin Jahe Merah (Zingiber officinale var. rubrum). 2006.

10. Wahid M, Karuniawati A, Kiranasari A, Ikaningsih, Kadarsih R. Emerging Resistance Pathogen : Situasi Terkini di Asia, Eropa, Amerika Serikat, Timur Tengah dan Indonesia. Majalah Kedokteran Indonesia. 2007;57 75-9.

11. Dipanwita R, Sukanta S, Saha S, Nath Dutta R. A Preliminary Sentinel Surveillance Report on Antibiotics Resistance Trend of Streptococcus pyogenes in Kolkata Region, India. Al Ameen J Med Sci. 2010;3:146-51.

12. Anggraini SM, Kurniawati H. Hubungan Faringitis Kronik dengan Riwayat Konsumsi Makanan Minuman Ekstrem Secara Suhu dan Rasa. 2011.

13. Retno Kusumawardani I, Kusdarwanti R, Handijatno D. Daya Anti Bakteri Ekstrak Jahe Merah (Zingiber officinale Rosc) dengan Konsentrasi yang Berbeda terhadap Pertumbuhan Aeromonas hydrophila Secara In Vitro. Berkala Ilmiah Perikanan. 2008;3 75-82. 